$1-1-2013$

\title{
Teaching Legal History in the First Year Curriculum
}

Christian G. Fritz

University of New Mexico - School of Law

Follow this and additional works at: https://digitalrepository.unm.edu/law_facultyscholarship

Part of the Law Commons

\section{Recommended Citation}

Christian G. Fritz, Teaching Legal History in the First Year Curriculum, 53 American Journal of Legal History 379 (2013).

Available at: https://digitalrepository.unm.edu/law_facultyscholarship/620

This Article is brought to you for free and open access by the UNM School of Law at UNM Digital Repository. It has been accepted for inclusion in Faculty Scholarship by an authorized administrator of UNM Digital Repository. For more information, please contact amywinter@unm.edu, Isloane@salud.unm.edu,sarahrk@unm.edu.

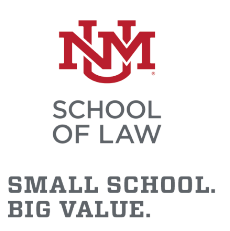

BIG VALUE. 


\section{Teaching Legal History in the First Year Curriculum \\ by Christian G. Fritz*}

INTRODUCTION

Legal history has been a required first-year class at the University of New Mexico School of Law since 1987, when I joined the faculty to develop such a course. Initially entitled "Historical Introduction to Law," the course reflected its title: an initial exposure to the historical context of the common law. Gradually, however, the course's focus evolved and by 1996 it was renamed "Comparative and Historical Legal Perspectives," or CHLP, to reflect a broader orientation of the legal system. While still providing historical context, CHLP is intended to help the entering class develop effectiveness and proficiency as law students and ultimately as lawyers.

II

\section{“LEARNING TO THINK LIKE A LAWYER”}

Although the readings in CHLP are very different from what students use to learn "the law" in their other first year classes, I argue that the course is directly relevant to their study and practice of law. I seek to advance this practical objective by using two approaches.

The first approach is to help students develop an appreciation of the intrinsic nature, characteristics, and particularities of the common law tradition. Law students are told that the principal objective of their training and education is to be able "to think like a lawyer."

\footnotetext{
* Henry Weihofen Chair in Law and Professor of Law, University of New Mexico (fritz@law.unm.edu). B.A., Ph.D., University of California-Berkeley; J.D., University of California-Hastings College of Law.
} 
While this platitude has some truth, it is, of course, not strictly accurate. More precisely, American law students are being taught "to think like a (common law) lawyer." A reminder that the legal system for which students are being trained is derived from a particular legal tradition underscores the easily-overlooked fact that there are significantly different understandings of the nature of "law" and the role for lawyers and judges within a host of other cultures and legal traditions.

For law students, acquiring the capacity to "think like a lawyer" in the common law tradition is akin to developing fluency in a new and complex language. The ability to communicate effectively and persuasively rests on a mastery of vocabulary, grammar, and syntax, as well as an appreciation of subtleties of pronunciation, context, dialects, and specialized argot. CHLP challenges students to immerse themselves and develop a sophisticated understanding of the conventions and byways of the particular legal culture within which American lawyers and judges operate.

The second approach in helping students develop into effective legal practitioners involves instilling a critical and self-conscious methodology to the study and understanding of law. Such a perspective is needed to resist the tendency of students to take what they are encountering for granted, as though it was inevitable and inexorable. I offer the metaphor that first year law students (under the conventional pedagogy followed by most American law schools) are dropped into an ocean of "law" where they quickly encounter a bewildering array of strange denizens in that watery legal world and in which they are largely left to their own devices to navigate and understand. As sentient creatures, law students know they have been dropped in this ocean, but there is a strong tendency to lose sight of this fact and begin to take the process of legal education and the content of law at face value.

CHLP challenges students to become "flying fish" who rise above the legal sea they find themselves in and attain a critical perspective from which they are encouraged to ask what they are doing in their other first year classes, how they are doing it, and why they are doing it. In addition to remaining critical consumers of their legal education, students are urged to embrace the central insight and legacy of legal realism: that legal rules and doctrines are not inevitable and that law rests on underlying and often implicit assump- 
tions; reflects particular values; and ultimately is a construct that is shaped rather than something that is inexorably or neutrally developed.

\section{III \\ READINGS}

CHLP seeks to advance these objectives in five interrelated units of readings. The first unit provides an overview of the common law and civil law tradition and starts with three appellate judicial opinions drawn from the highest civil court in France, the highest civil court in Germany, and from the Michigan Supreme Court. All three courts address an identical issue (the tort principle of joint and several liability) and each reaches the same result in applying the principle. Even so, the judicial opinions look very different. I ask the students to think of the judicial opinions as "artifacts" of the legal systems that produced them-the first two from the civil law tradition and the last from the common law tradition. The opinions vary dramatically in terms of length, sources of law, and the nature of judicial persona and argumentation. These differences invite an exploration of how the history and nature of the civil law tradition helps account for the shape of the French and German opinions.

Although the first unit serves to introduce students to the civil law tradition, the ostensible purpose of the comparative approach is to highlight features of the Michigan decision that underscore characteristics of the common law approach to judicial law-making that might otherwise be taken for granted. The Michigan case serves as a typical example of the appellate opinions that form the staple of what students are reading for their other classes, but which allows them to reflect upon how the American opinion suggests a different world view of the nature of law and the legitimate sources of law.

Unit two turns to selected aspects of the history of the common law tradition, including the unification of law in England through the rise of the royal courts operating under the writ system and the emergence of the court of Chancery, along with the legacy of the law/equity distinction and the ultimate procedural "merger" of the two. The readings dealing with medieval English legal developments and American law reform in the 19th century do not pretend to 
offer an overview of English and American legal history. Rather, they serve as a means through which students can identify contributing factors that have shaped the common law tradition and given it particular characteristics and features. The comparison of the three judicial opinions that began the class continues to provide benefits as students are able to identify further parallels between the Michigan opinion and the appellate opinions they are studying in the context of being introduced to criminal law, torts, and contracts.

Unit three, "The Role of Law and Lawyers," shifts gears by introducing some "non-Western" concepts of law, including dimensions of Chthonic legal traditions and Navajo justice concepts. The unit offers the opportunity to see commonalities between the common law and civil law traditions (despite the distinctions prompted by a comparison of the traditions in unit one) in contradistinction with other cultural contexts in which the meaning of "law" and the role of lawyers-if any-is rather different from what those working within both the common law and civil law traditions might take for granted. This third unit also explores expectations about law and lawyers in the American common law tradition, the contours of an ideology of advocacy, and the broad trends in the rise of "Alternative Dispute Resolution." Just as cultural understandings about the nature of "law" shape the potential role for lawyers, that understanding obviously underlies how law is taught.

Unit four turns to the question that first semester law students invariably ask: where did the pedagogy for legal education that they are experiencing come from? The unit permits a brief exploration of the arc of legal education from a practical, apprentice-based approach exemplified by training in the Inns of Court and by "reading law" to a combination of academic study and apprenticeships to Christopher Columbus Langdell's concept of law as a "science." Exploring the rise of the modern law school in terms of the study of law introduced with Langdell's deanship at Harvard in 1870 helps satisfy the curiosity of students about the birth of the "Socratic method." At the same time, that story permits an introduction of a jurisprudential perspective of American law by exploring the premises, methods, and purposes of Langdell's legal education. The philosophy and understanding of law that underlay Langdell's "revolution" in legal education set the stage for the ultimate rejection of "Langdellism" in the critiques of the Legal Realists. 


\section{IV \\ CONCLUSION}

The final unit of the course, "Changing Perceptions of Law in America," traces the emergence of the Legal Realists and some of their intellectual heirs, including Critical Legal Studies, Feminist Jurisprudence, and Critical Race Theory. Whether students find these approaches compelling is beside the point; all I hope to do is challenge them to think about law critically and to examine what has shaped law and the legal system. If students leave the course and become more like "flying fish," then the course has done its job. 